\title{
Phellinus linteus polysaccharide extracts increase the mitochondrial membrane potential and cause apoptotic death of THP-1 monocytes
}

\author{
Leo JLD van Griensven ${ }^{*}$ and Harrie A Verhoeven
}

\begin{abstract}
Background: The differentiation resp. death of human monocytic THP-1 cells induced by polysaccharide extracts of the medicinal mushrooms Phellinus linteus, Agaricus bisporus and Agaricus brasiliensis have been studied. This study aims to identify leads for the causal effects of these mushroom components on cell differentiation and death.

Methods: THP-1 cells were treated with different polysaccharide extracts of mushrooms and controls. Morphological effects were observed by light microscopy. Flow cytometry was applied to follow the cell differentiation by cell cycle shifts after staining with propidium iodide, changes of mitochondrial membrane potential after incubation with JC-1, and occurrence of intracellular reactive oxygen species after incubation with hydroethidine. Principal component analysis of the data was performed to evaluate the cellular effects of the different treatments.

Results: $P$. linteus polysaccharide extracts induced dose-dependent apoptosis of THP-1 cells within 24 h, while A. bisporus and A. brasiliensis polysaccharide extracts caused differentiation into macrophages. A pure $P$. linteus polysaccharide had no effect. Apoptosis was inhibited by preincubating THP-1 cells with human serum. The principal component analysis revealed that $P$. linteus, A. bisporus and A. brasiliensis polysaccharide extracts increased reactive oxygen species production. Both $A$. bisporus and $A$. brasiliensis polysaccharide extracts decreased the mitochondrial membrane potential, while this was increased by $P$. linteus polysaccharide extracts.

Conclusions: $P$. linteus polysaccharide extracts caused apoptosis of THP-1 monocytes while A. bisporus and A. brasiliensis polysaccharide extracts caused these cells to differentiate into macrophages. The protective effects of human serum suggested that $P$. linteus polysaccharide extract induced apoptosis by extrinsic pathway, i.e. by binding to the TRAIL receptor. The mitochondrial membrane potential together with reactive oxygen species seems to play an important role in cell differentiation and cell death.
\end{abstract}

\section{Background}

Phellinus linteus is a basidiomyceteous mushroom that has been used for centuries as a traditional medicine in China, Korea and Japan for the treatment of various cancers and inflammation related diseases [1,2].

The medicinal effects of $P$. linteus have been attributed to $\beta$-glucans, phenols and terpenes [3,4]. The $\beta$-glucans are immunomodulators that can either enhance or attenuate the immune system of higher animals by inducing or inhibiting the production of pro- and anti-

\footnotetext{
*Correspondence: leo.vangriensven@wur.nl

Department of Bioscience, Plant Research International, Wageningen

University and Research Centre, Droevendaalsesteeg 1, Wageningen 6700AA, The Netherlands
}

inflammatory cytokines [3]. The phenols, diterpenes and triterpenes had antioxidative effects and inhibited inflammatory mediators [5], which could prevent liver damage in rat and offer alternatives to the currently used antidiabetic agents [6]. P. linteus polysaccharide extracts are strongly antioxidative, and the purified polysaccharides comprise a mixture of $90 \% \beta-(1 \rightarrow 3)(1 \rightarrow 6)$ glucan and $10 \% \alpha$-glucan consisting of $85 \%$ glucose [7].

In experimental systems direct inhibitory effects of mushroom extracts on various tumors and tumor cell lines are caused by blockade of the cell cycle, apoptosis or both. Apoptosis is an essential process for tissue homeostasis, and its dysregulation might directly involve in initiation and progression of cancer [8]. Many studies

\section{Biomed Central}


have indicated that the upregulation of apoptosis or resensitization of cells to apoptotic stimuli showed promising potential for cancer therapy $[9,10]$. Apoptosis is initiated through extrinsic (death receptor mediated) and intrinsic (mitochondrion mediated) pathways [9]. Caspases, enzymes which belong to a growing family of cysteine proteases play an intermediary role. These enzymes are produced after death receptor binding (extrinsic pathway) and after cytochrome $\mathrm{C}$ release from damaged mitochondria (intrinsic pathway) [11].

A partially purified $P$. linteus polysaccharide extract significantly prolonged the survival rate of B16F10 melanoma implanted mice, inhibited tumor growth in NCIH23 implanted nude mice, and reduced the pulmonary metastasis frequency of melanoma [12]. It could sensitize human prostate cancer cells to apoptosis both in vitro [13] and in vivo in nude mice [14]. Many cancer cell lines showed growth inhibition or apoptosis when treated by partially purified ethanol extracts of $P$. linteus and by the phenolic compounds hispolon or inotilone derived from these extracts [15]. Aqueous $P$. linteus extracts containing both water and ethanol soluble compounds induced cell cycle arrest [16], and apoptosis of cancer cells in vitro and in vivo [17-19].

Kim et al. [5] and Huang et al. [20] found that P. linteus organic extracts inhibited NF- $\mathrm{kB}$, MMP-9 and MAPK activation in vivo and in vitro, leading to the conclusion that $P$. linteus may present a therapeutic approach for inflammation-associated disorders such as rheumatoid arthritis, psoriasis and other autoimmune afflictions. Shnyreva et al. [21] found that treatment of K562 cells with $P$. linteus ethanol extract increased the expression of the anti-inflammatory cytokine IL-10. Hispidin from $P$. linteus is a $\beta$-secretase inhibitor and is considered an anti-Alzheimer's disease agent [22], while inotilone from $P$. linteus suppressed allergic inflammation in mice [20]. Suzuki et al. [23] demonstrated neuroprotective effects of a $P$. linteus culture filtrate in rats with ischemia induced cerebral infarction and Wang et al. [24] demonstrated curative effects of a P. linteus polysaccharide extract on thioacetamide-induced liver fibrosis.

We studied the differentiation of THP-1 cells, a human leukemia-derived monocytic cell line [25] after treatment with various extracts of P. linteus, Agaricus bisporus and Agaricus brasiliensis to assess the mechanisms underlying the $P$. linteus induced curative effects or alleviation of disease symptoms. Monocytes, dendritic cells and macrophages play important roles in host defense against infectious disease and cancer [26]. Activated macrophages produce cytokines and other inflammatory regulators such as COX-2, nitric oxide, and prostaglandins [27], leading to MAPK dependent signaling pathways and NF- $\mathrm{kB}$ dependent transcription regulation [28]. The purified $P$. linteus derived polysaccharides demonstrated the strong antioxidant effects and suppressed IFN- $\gamma$ in vitro [7].

This study aims to investigate the effects of $P$. linteus polysaccharide extracts on the differentiation and death of THP-1 monocytes.

\section{Methods}

\section{Chemicals, materials and equipment}

All chemicals were obtained from Sigma-Aldrich, The Netherlands, unless otherwise mentioned. All materials and equipment was obtained from the Dutch supplier or their Dutch representative, unless otherwise stated.

\section{Fungal materials}

Dried fruiting bodies of $A$. bisporus (Sylvan A15, i.e. strain Horst U, ATCC 62462) and of $A$. brasiliensis (Mycelia, Belgium, strain M7700) were obtained from the former Mushroom Experimental Station (Horst, The Netherlands), and wild $P$. linteus fruiting bodies were obtained from Amazing Grace Health Industries (Bangkok, Thailand) and had been identified by Dr. Usa Klinhom (University of Mahasarakham, Thailand). P. linteus samples were deposited in the collection of the Natural Medicinal Mushroom Museum of the Faculty of Biology of Mahasarakham University. Cordyceps militaris (L.) Link was donated by Dr. Jae-Mo Sung of Kangwon National University (Chuncheon, Korea). Saccharomyces cerevisiae (Bakers Yeast, Bruggeman, The Netherlands) was grown in malt extract medium with $2 \%$ glucose and collected by centrifugation.

\section{Cell and tissue culture}

The human leukemia cell lines THP-1 (Cell Lines Service, Eppelheim, Germany) and K562 were donated by Prof. Huub F.J. Savelkoul, (Department of Cell Biology and Immunology, Wageningen UR) were grown in RPMI 1640 culture medium (Sigma-Aldrich, cat. R8758) supplemented with $10 \%$ heat-treated newborn calf serum (Gibco, cat. 161010-159) and penicillin/streptomycin (SigmaAldrich), at $37^{\circ} \mathrm{C}$ in $5 \% \mathrm{CO}_{2}$ atmosphere in a humidified incubator. Human serum was purchased from Sanquin (Nijmegen, The Netherlands) and was a mixture of $\mathrm{O}, \mathrm{D}(+)$ sera obtained by centrifugation of peripheral blood.

\section{Purification of $P$. linteus, A. bisporus, A. brasiliensis and C. militaris polysaccharides}

Crude $P$. linteus extracts were obtained by fine grinding and sieving (size $<1 \mathrm{~mm}$ ) of dry fruiting body. Then hot water extraction was applied by autoclavation for $20 \mathrm{~min}$ in excess water.

Partially purified polysaccharides were precipitated by addition of 2 volumes of $96 \%$ ethanol. Precipitate was 
dissolved in water, dialyzed, reprecipitated and characterized as described in Kozarski et al. [7].

Pure $P$. linteus polysaccharides were purified from dry powder that was initially extracted for $16 \mathrm{~h}$ by ethanol at $65^{\circ} \mathrm{C}$. The extracted tissues were collected by centrifugation in a Sorvall RC5B centrifuge at $7000 \times g$ for $15 \mathrm{~min}$ and autoclaved twice in excess water $(\mathrm{v} / \mathrm{w}$ ratio $>5)$. The mash was centrifuged in a Sorvall RC5B centrifuge at $7000 \times g$ for $15 \mathrm{~min}$ and the resulting clear liquid was concentrated by evaporation in a Buchi R210 rotary evaporator at $45^{\circ} \mathrm{C}$. After an initial precipitation by 2 volumes of cold ethanol the polysaccharides were suspended in water and subjected to a SEVAG treatment [29] with chloroform:butanol $(6: 1)$ to remove the bulk of the proteins. After reprecipitation with 2 volumes of ethanol, the partially pure $P$. linteus polysaccharides were suspended in cold 10\% TCA to further remove protein remnants, and the liquid was clarified by centrifugation in a Sorvall RC5B centrifuge at $7000 \times g$ for $15 \mathrm{~min}$. Ethanol precipitation produced a white colored pellet of polysaccharide that, upon drying, was almost free of protein $(<0.1 \% \mathrm{w} / \mathrm{w})$ and phenolic compounds $(<0.35 \% \mathrm{w} / \mathrm{w})$ and was easily solved in water.

Ethanol extract was evaporated until dry and resuspended in ethanol. Insoluble components were removed by centrifugation in an Eppendorf F45 centrifuge at $10.000 \times g$ for $10 \mathrm{~min}$. All preparations were routinely quantified for polysaccharide content [30], phenol content by Folin-Ciocalteu assay [31], and protein content by Coomassie Brilliant Blue staining [32]. P. linteus polysaccharide extract was composed of approximately $90 \%$ $\beta-(1 \rightarrow 3)(1 \rightarrow 6)$ glucan and $10 \% \alpha$-glucan and consisted of $85 \%$ glucose [7].

Polysaccharides were obtained by hot water extraction of A. bisporus, A. brasiliensis, and C. militaris powders as described before [7]. A. bisporus polysaccharide consists of glucose, galactose and mannose and contains $(1 \rightarrow 4)(1 \rightarrow 6) \alpha$-glucan, $(1 \rightarrow 6)$ - $\beta$-glucan and mannogalactan; $A$. brasiliensis has a higher content of $\beta$-glucan, while $A$. bisporus has mannogalactan as its main polysaccharide [33].

\section{Scavenging activity}

All polysaccharide extracts were investigated for their free radical scavenging activities by employing the stable free radical 2,2'-diphenyl- $\beta$-picrylhydrazyl (DPPH) (SigmaAldrich D-9132). DPPH was dissolved in 96\% ethanol, and $1 \mathrm{~mL}$ was mixed with $0,2,5,10,20$ and $50 \mu \mathrm{L}$ of the extract in ethanol or water; appropriate standard ranges of gallic acid color controls were run in each series. Incubation was for $30 \mathrm{~min}$ at room temparature. Mixtures were centrifuged in an Eppendorf F45 centrifuge at $10.000 \times g$ for $10 \mathrm{~min}$. The absorbance of the reaction mixture was measured in quadruplicate at $485 \mathrm{~nm}$ in a 96 well plate using a Tecan (Switzerland) Sunrise 96 well microplate reader. The $\mathrm{IC}_{50}$ of the polysaccharides was determined and compared with the corresponding value for a concentration range of $0-200 \mu \mathrm{M}$ Trolox. As a standard, the $\mathrm{IC}_{50}$ for Trolox in the DPPH assay was determined to be $35 \mu \mathrm{M}$.

\section{THP-1 differentiation and stimulation}

The mature macrophage-like state was induced by treating THP-1 monocytes $(500,000$ cells $/ \mathrm{mL})$ for $1-2$ days with $40 \mathrm{ng} / \mathrm{mL}$ phorbol 12-myristate 13-acetate (PMA; Sigma-Aldrich, cat.nr. 79352) in 24-well cell culture plates (Corning Costar $^{\odot}$ from Sigma-Aldrich) with $1 \mathrm{~mL}$ cell suspension in each well. For the mushroom extracts, THP-1 cells were treated analogously. Cells received up to $1 \mathrm{mg}$ of crude extract per $\mathrm{mL}$ and were daily checked for morphological changes under a Zeiss Axiovert 35 microscope. Cells were washed with phosphate buffered saline (PBS) (Sigma-Aldrich, cat.nr. T6146), fixated with 4\% buffered formaldehyde and stained with $0.2 \%$ crystal violet (Sigma-Aldrich, cat.nr. V5265) in water to directly observe morphological changes and to quantitate the rate of differentiation. For the latter wells were shaken with $0.5 \mathrm{~mL}$ 96\% ethanol and the absorption of the ethanol was measured at $590 \mathrm{~nm}$.

\section{Trypan blue and fluorescent staining}

Cell culture samples $(15 \mu \mathrm{L})$ were taken from cell cultures and 1 volume of sterile filtered 0.4\% trypan blue in PBS was added. After 3-4 min, cells were counted in a Fuchs-Rosenthal hemocytometer by a Zeiss Axioskop 40 microscope. For fluorescent staining, cells were washed with PBS and fixated in $4 \%$ buffered formaldehyde. Staining was performed by adding $10 \mu \mathrm{L}$ of a mixture of $1 \%$ acridine orange (AO) (Sigma-Aldrich A9231) and $0.1 \%$ ethidium bromide (EB) (Sigma-Aldrich E 1510) in ethanol to $1 \mathrm{~mL}$ of cell suspension. Cells were observed in a Zeiss Axioskop, by excitation/emission wave lengths of $485 \mathrm{~nm}$ resp. $535 \mathrm{~nm}$. As a rule experiments were repeated twice; for trypan blue 5 counts of at least 200 cells per point were carried out. For AO/EB staining a minimum of 500 cells was counted.

\section{Phagocytic activity}

Green fluorescing polymer microspheres $(0.01 \%(\mathrm{w} / \mathrm{v}))$ of $1 \mu \mathrm{m}$ size (G100, Duke Scientific Corp. USA) in PBS were opsonized by incubation with $10 \%(\mathrm{v} / \mathrm{v}) \mathrm{hu}-$ man serum for $1 \mathrm{~h}$ at $37^{\circ} \mathrm{C}$. The particles were then washed with PBS. Phagocytosis was visualized by a Zeiss Axioskop after cells had been incubated for $16 \mathrm{~h}$ at $37^{\circ} \mathrm{C}$ with $10 \mu \mathrm{L}$ microsphere suspension per $\mathrm{mL}$ cell culture. 


\section{Flow cytometry}

For cell cycle analysis using propidium iodide cells were collected from culture medium after 24 resp. $48 \mathrm{~h}$ cultivation by centrifugation in an Eppendorf F45 centrifuge at $80 \times g$ for $10 \mathrm{~min}$ at $4^{\circ} \mathrm{C}$ and washed in cold PBS. Fixation was done with $70 \%$ ethanol for $30 \mathrm{~min}$ on ice; cells were then suspended in PBS and incubated with $40 \mu \mathrm{g} / \mathrm{mL}$ RNase A (Sigma-Aldrich, cat.nr. R6513) at room temperature for $1.5 \mathrm{~h}$ before starting cytometry, propidium iodide (PI) was added at $5 \mu \mathrm{g} / \mathrm{mL}$. For ROS (reactive oxygen species) and MMP (mitochondrial membrane potential) measurements, experiments were performed in duplo, with one replicate stained with $2 \mu \mathrm{M}$ JC-1 (Life Technologies Corporation cat. nr. T-3168)] and the other with $5 \mu \mathrm{M}$ dihydroethidium (DHE, Sigma-Aldrich cat.nr. 37291).

A DAKO Cyan instrument (Beckman-Coulter Inc USA) was used for flowcytometric analysis, equipped with a $488 \mathrm{~nm}$ solid state blue green laser, operated at $10 \mathrm{~mW}$ output power. The standard filter/dichroic mirror set was used, and four fluorescence, forward scatter and sideward scatter signals were recorded, in both logarithmic and linear mode. Data were collected from the samples during a run of $30 \mathrm{~s}$ per sample. In this way, about 1500 to 6000 cells were analyzed during every run, allowing a comparison of cell growth or toxic effects of the treatments. Gating was applied in the forward/sideward scatter diagram to select for intact cells. Flow cytometry data were recorded in fcs 3 file format and analysed using the free version of Cyflogic, version 1.2.1 (Cyflo Ltd, Finland). Selected data (fluorescence intensity, forward and sideward scatter) were exported to Excel for statistical analysis, using the StatistiXL version 1.8 (StatistiXl, Australia) plug-in.

Principal component analysis (PCA) was used to reveal complex interactions between various cellular properties to identify the discriminating parameters in the various treatments. The casewise PCA scores were plotted as round dots in graphs with the relevant PC's on the horizontal and vertical axis. Component Score Coefficients (Eigenvectors) were indicated in these graphs with small squares as endpoint and identified by the parameters they are representing. For analysis of the cell cycle data (linear mode), signals were gated on pulse time to remove debris and cell aggregates. The gated fluorescence intensity histogram was divided into 4 regions, representing G1/G0, S and G2 phase of the cell cycle, with below G1 taken for induction of apoptosis (nuclear fragmentation) noise. Individual samples were normalized for cell number and cell number was added as an individual parameter to the PCA. Mitochondrial membrane polarization and ROS induction were cell parameters extracted respectively from $\mathrm{JC}-1$ and $\mathrm{DHE}$ stained cells.
All data, except pulse duration, were recorded in logarithmic mode and represented as median value with $\mathrm{CV}$, whereas pulse duration was represented as mean with CV. The entire data matrix was analyzed by PCA using StatistiXL v.1.8 (StatistiXl, Australia).

\section{Statistics}

analysis

Statistica for Windows - release 5.0 (StatSoft Inc., Tulsa, USA) was used for the analysis of variance (ANOVA). All experiments were at least twice repeated. Measurements within an experiment were done in triplicate or quadruplicate and data were expressed as mean \pm standard deviation (SD). The experimental data were subjected to ANOVA and Fisher's LSD (least significant difference) test was performed to detect any significant difference $(P<0.05)$. Visual inspection showed dose-dependence after statistical preprocessing.

\section{Results and discussion THP-1 differentiation}

The effects of different polysaccharide extracts on the differentiation of monocytic THP-cells into macrophages were shown in Table 1 . When THP-1 cells were incubated for $24 \mathrm{~h}$ with partially purified polysaccharide extracts of $A$. bisporus or $A$. brasiliensis, the cellular morphology changed from round cells growing in suspension to spindle shaped cells adhering to the wall of the culture plate (Figure 1c). This morphological change appeared analogous to the changes in THP-1 cells

\section{Table 1 Effects of different extracts on differentiation of} monocytic THP-1 cells into macrophages

\begin{tabular}{|c|c|c|c|}
\hline Species/Type & $\begin{array}{l}\text { Macrophage-like } \\
\text { morphology }\end{array}$ & $\begin{array}{l}\text { Time required } \\
\text { for changes }(\mathrm{h})\end{array}$ & Cytopathogenicity \\
\hline A. bisporus & ++++ & $24-48$ & \\
\hline A. brasiliensis & ++++ & $24-48$ & \\
\hline C. militaris & +++ & $24-72$ & After $24 \mathrm{~h}$ cell death \\
\hline P. linteus & - & 24 & After $24 \mathrm{~h}$ apoptosis \\
\hline $\begin{array}{l}\text { S. cerevisiae } \\
\text { (baker's yeast }\end{array}$ & - & & \\
\hline Avena sativa (Oat) & - & & \\
\hline PMA (40 ng/mL) & ++++ & $48-96$ & \\
\hline LPS (1 $\mu \mathrm{g} / \mathrm{mL})$ & ++ & 72 & \\
\hline Laminarin & - & & \\
\hline Zymosan & + & 48 & \\
\hline $\begin{array}{l}\text { Fixated E.coli } \\
\left(5 \times 10^{8} / \mathrm{mL}\right)\end{array}$ & ++ & 72 & \\
\hline
\end{tabular}

THP-1 cells were cultivated in 24 well plates in RPMI 1640 complete medium to which polysaccharide extracts respectively activators had been added at $1 \mathrm{mg} / \mathrm{mL}$ unless otherwise stated. After $24 \mathrm{~h}$ culture medium was decanted and cells were washed in PBS, fixated with $4 \%$ buffered formaldehyde and stained by $0.2 \%$ crystal violet as described in Methods: THP-1 differentiation and stimulation. Non-adhering cells as treated by $P$. linteus polysaccharide extract were collected and PBS washed by centrifuging at $80 \times g$ for $5 \mathrm{~min}$ in an Eppendorf 45 centrifuge. 


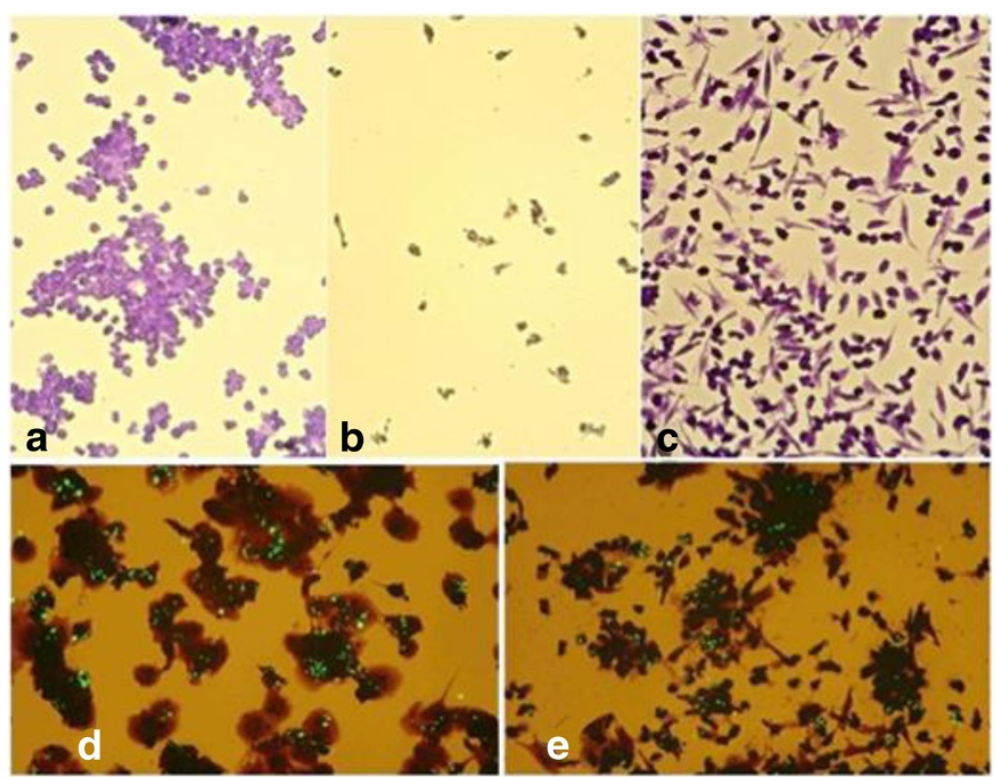

Figure 1 THP-1 cells cultivated for $24 \mathrm{~h}$ with PMA (a), no addition (b) and $1 \mathrm{mg} / \mathrm{mL}$ A. bisporus polysaccharide extract (c); comparison of phagocytotic activity after PMA treatment (d) and A. bisporus polysaccharide extract treatment (e). Cells were cultivated in a 24 wells plate, washed with PBS, fixated in $4 \%$ formaldehyde and stained by crystal violet. Figure 1a shows that PMA treated cells form aggregates after $24 \mathrm{~h}$ incubation and adhere to the plate. Figure $1 \mathbf{b}$ shows that non treated control cells do not adhere and are washed away. Figure 1c shows the effect of $A$. bisporus polysaccharide extract, stretching of the originally rounded cells, and adherence to the plate. Figure $1 \mathbf{d}$ shows the uptake of fluorescent latex particles in PMA treated THP-1 cells and Figure 1e shows uptake of particles in A. bisporus polysaccharide extract treated cells.

induced by phorbol 12-myristate 13-acetate (PMA), which converted THP-1 monocytes into macrophages [34]. In addition, the $A$. bisporus polysaccharide extract-treated THP-1 cells could absorb (fluorescent) latex particles of $1 \mu \mathrm{m}$ diameter analogously to PMA activated THP-1 cells (Figure $1 \mathrm{~d}$ and $1 \mathrm{e}$ ). The $A$. bisporus and $A$. brasiliensis polysaccharide extracts induced differentiation within $24 \mathrm{~h}$ whereas that induced by PMA required at least 48-72 $\mathrm{h}$ (Table 1). The effects of a $24 \mathrm{~h}$ incubation with PMA on THP-1 cells were adherence, enlargement, and clustering. In the following $24-48 \mathrm{~h}$, the cells differentiated into stretched spindle-shaped cells. A C. militaris polysaccharide extract caused initial wall adherence and spindle cell formation that quickly led to cell death. Laminarin, a linear $\beta-(1 \rightarrow 3)$-glucan with $\beta$ - $(1 \rightarrow 6)$ side chain branching on every tenth glucose unit along the polymer backbone [35], purified from the seaweed Laminaria digitata, had no differentiating effect, whereas zymosan, a $\beta-(1 \rightarrow 3)(1 \rightarrow 6)$-glucan rich protein carbohydrate complex from Saccharomyces cerevisiae had a limited differentiation-inducing effect (Table 1). The bacterial toxin lipopolysaccharide (LPS) as well as fixated Escherichia coli induced differentiation of THP-1 cells. Oat $\beta-(1 \rightarrow 3)(1 \rightarrow 4)$-glucan and Saccharomyces sp.-derived polysaccharides had no effects (Table 1). A possible explanation for the differentiation inducing activity of the Agaricus polysaccharide extracts is the presence of ergosterol derived
$1 \alpha, 25$-dihydroxyvitamin D in the extracts [36,37]. Unlike $P$. linteus, $A$. bisporus and $A$. brasiliensis fruiting bodies contained large amounts of lipid-soluble ergosterol which can be metabolized into hydroxylated vitamin D2 and vitamin D4 [36,37]. The hydroxylated vitamin D3, a secosteroid of hydroxylated vitamin D2, binds to the vitamin $\mathrm{D}$ receptor on cells and plays a role not only in calcium uptake but also in differentiation [36,37]. Epidermal cells are an example; treatment with hydroxylated vitamin D3 improved calcium homeostasis and abolished proliferation [38]. Vitamin D3 and PMA increased macrophage differentiation of THP-1 cells, although vitamin D3 was less effective than PMA [34]. The morphological effects of PMA, A. bisporus and $A$. brasiliensis polysaccharide extracts on THP-1 cells were illustrated in Figure 1a and 1c, respectively.

Contrary to the A. bisporus- and A. brasiliensis-induced effects, a partially purified $P$. linteus polysaccharide extract induced strong cell shrinkage, nuclear condensation, and fragmentation into apoptotic bodies after $24 \mathrm{~h}$ of exposure (Figure 2), leading to complete cell death within $48 \mathrm{~h}$. The clear apoptotic volume decrease of the cells (Figure 2a) was caused by activation of $\mathrm{K}^{+}$or $\mathrm{Cl}^{-}$channels resulting in $\mathrm{KCl}$ efflux and exit of osmotically obliged water [39]. The induced apoptosis was polysaccharide extracts concentration-dependent and reached 100\% of the cell population at $375 \mu \mathrm{g} / \mathrm{mL}$ after $24 \mathrm{~h}$ of incubation 

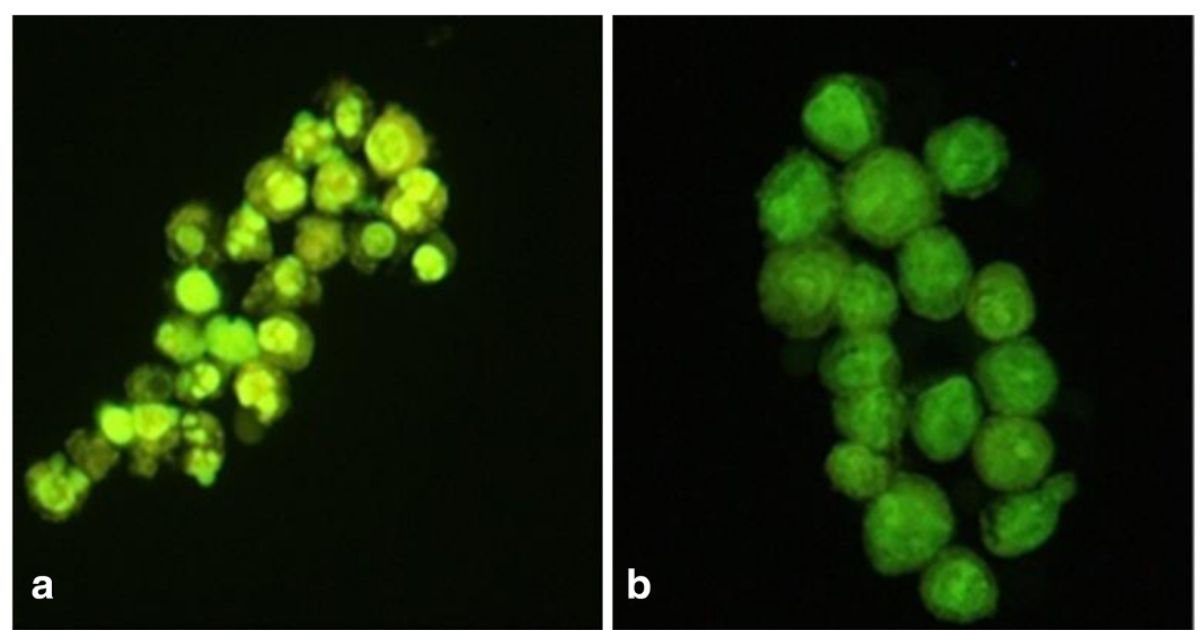

Figure 2 Effect of partially purified P. linteus polysaccharide extract on the morphology of THP-1 cells. (a) THP-1 cells cultivated with $1 \mathrm{mg} / \mathrm{mL}$ P. linteus polysaccharide extract for $24 \mathrm{~h}$. Cells show strong shrinkage, nuclear condensation and nuclear fragmentation into apoptotic bodies. Cells were stained with an AO/EB mixture and immediately photographed using excitation/emission at 485/530 nm using a 20x objective. (b) Control THP-1 cells.

in the presence of $P$. linteus polysaccharide extracts (Figure 3). Student's $t$-test showed that only the increase from $375 \mu \mathrm{g} / \mathrm{mL}$ to $750 \mu \mathrm{g} / \mathrm{mL}$ was the only one that showed no significant difference $(P=0.3)$ because the plateau value for the apoptotic percentage had been reached. In addition, the ethanol extract of $P$. linteus induced an analogous concentration-dependent apoptosis. At higher concentrations than the optimal values, most cells were decomposed into hardly recognizable remnants (Figure 3). The pure polysaccharide from $P$. linteus fruiting bodies contained less than $0.1 \%(\mathrm{w} / \mathrm{w})$ protein as measured by the Bradford assay and less than $0.35 \%$ phenolic compounds (gallic acid equivalents) as measured by the Folin-Ciocalteu assay. This polysaccharide was free of DPPH-dependent scavenging activity. The pure P. linteus polysaccharide did not induce apoptosis in THP-1 cells, even at a concentration of $1 \mathrm{mg} / \mathrm{mL}$ culture medium. We incubated both THP-1 cells and human myeloid leukemia K562 cells with $1 \mathrm{mg} / \mathrm{mL}$ partially purified polysaccharide extracts for 24,48 , and $72 \mathrm{~h}$, and determined the cell numbers and viability by the trypan blue exclusion assay to further test the cytopathic effect of $P$. linteus polysaccharide on cell growth (Figure 4). The P. linteus polysaccharide extracts caused significant inhibition of THP-1 cell
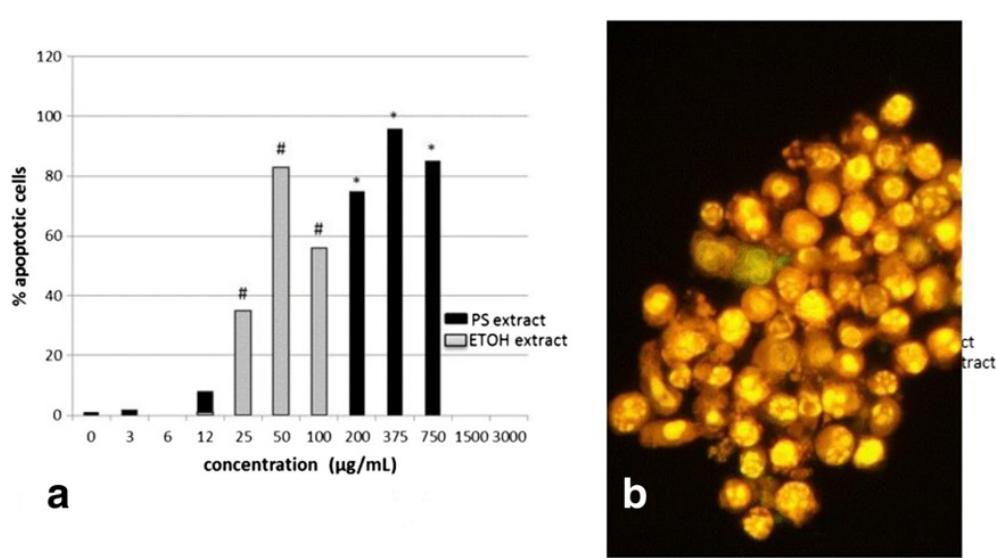

Figure 3 Concentration-dependent induction of apoptosis in THP-1 cells. Cells were cultivated for $24 \mathrm{~h}$ in the presence of different concentrations of partially purified $P$. linteus polysaccharide extract, respectively of ethanol extract of $P$. linteus. Cells were collected by centrifugation, fixated in $4 \%$ buffered formaldehyde and stained by AO/EB. A minimum of 500 cells was counted per point. Observation at excitation/emission at 485/530 nm, using a 20x objective. (a) Dose effect graph. (b) Microphoto of THP-1 cells treated by $375 \mu \mathrm{g} P$. linteus polysaccharide extract $/ \mathrm{mL}$ medium. ${ }^{*}$ and ${ }^{\#} P<0.05$, significantly different from the previous values of the same concentration range. 


\section{a Effect of polysaccharides on THP-1 growth}

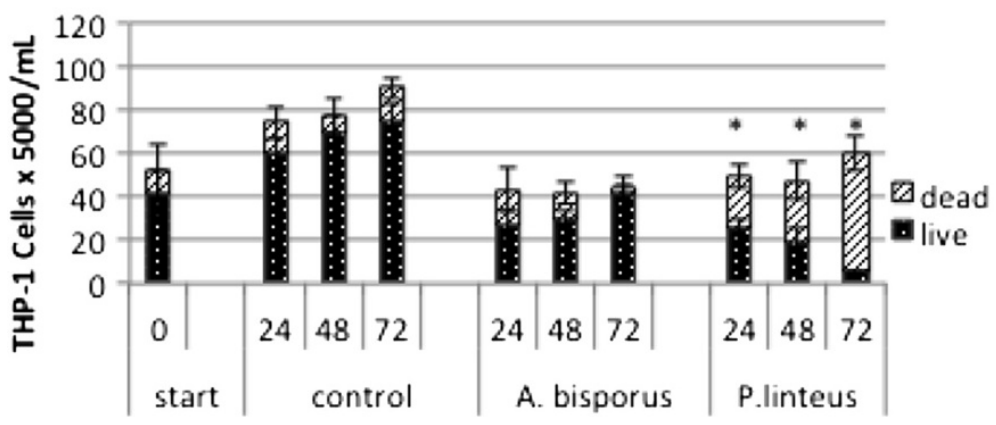

Polysaccharide origin and time (hours) of incubation

\section{b Effect of polysaccharides on K562 growth}

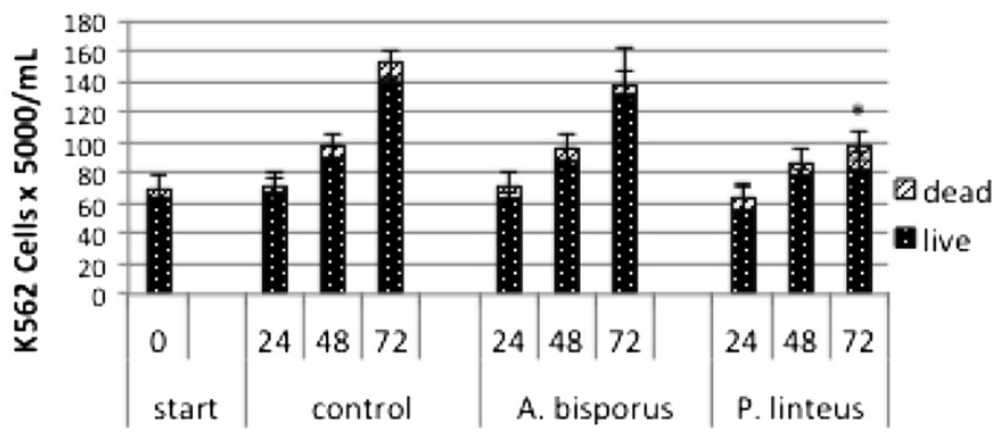

Polysaccharide origin and time (hours) of incubation

Figure 4 Effect of $A$. bisporus polysaccharide extract and of $P$. linteus polysaccharide extract on the growth of THP-1 (a) and K562 cells (b). Samples were taken at 24, 48 and $72 \mathrm{~h}$ after the start of incubation; counting was performed using trypan blue and non-colored cells were considered "live". Blue cells were considered "dead". A minimum of 500 cells cells was counted per point. * $P<0.01$, significantly different from the values of the control group.

growth after $24 \mathrm{~h}(P=0.001)$ and $48 \mathrm{~h}(P=0.007)$ and complete cell death after $72 \mathrm{~h}$. The human leukemia cell line K562 was identically incubated with the same extract samples. The $P$. linteus polysaccharide extracts led to significantly slower cell growth than the control cells only after $72 \mathrm{~h}(P=0.001)$. No increase in apoptotic cell death was observed in K562 cells incubated with the $P$. linteus polysaccharide extracts, indicating a specific interaction between the $P$. linteus polysaccharide extracts and THP-1 cells, rather than a general toxicity.

Although both cell lines have a myeloid origin, THP-1 cells can differentiate into macrophages, while K562 differentiate into the erythroid direction. The cytopathogenicity for THP-1 cells did not change after opsonization of $P$. linteus polysaccharide extracts with excess complete human serum. However, when THP-1 cells were incubated with $1 \mathrm{mg} / \mathrm{mL}$ of $P$. linteus polysaccharide extracts and $5 \%$ (v/v) complete human serum, no cytopathic effect was observed: the THP-1 cells adhered to the wall of the culture plate and developed a phagocyte-like morphology. The same effect was observed when THP-1 cells were treated with the $P$. linteus polysaccharide extracts after preincubation of the cells for $6 \mathrm{~h}$ with complete human serum. The protection against $P$. linteus-induced cytotoxicity was dose-dependent in a range of $0.5-10 \%$ serum (Figure 5). Decomplementation of the human serum (heat treatment for $20 \mathrm{~min}$ at $58^{\circ} \mathrm{C}$ ) had no effect on its protective activity. When freshly isolated human peripheral blood monocytes (PBMC's) were treated with $P$. linteus polysaccharide extract, a considerable part of the monocyte population differentiated into wall adhering macrophage like cells within $24 \mathrm{~h}$ (Figure 6). The difference in effects between THP-1 cells and PBMC's might be explained by the fact that the PBMC's were directly derived from a human serum protein environment, whereas the THP-1 cells had been cultured in calf serum for many generations leading to different receptor saturation. Freshly isolated PBMC's, contrary to-THP-1 cells, seemed to be naturally protected against the deleterious apoptosisinducing effects of $P$. linteus polysaccharide extracts through binding of protective human serum components. 


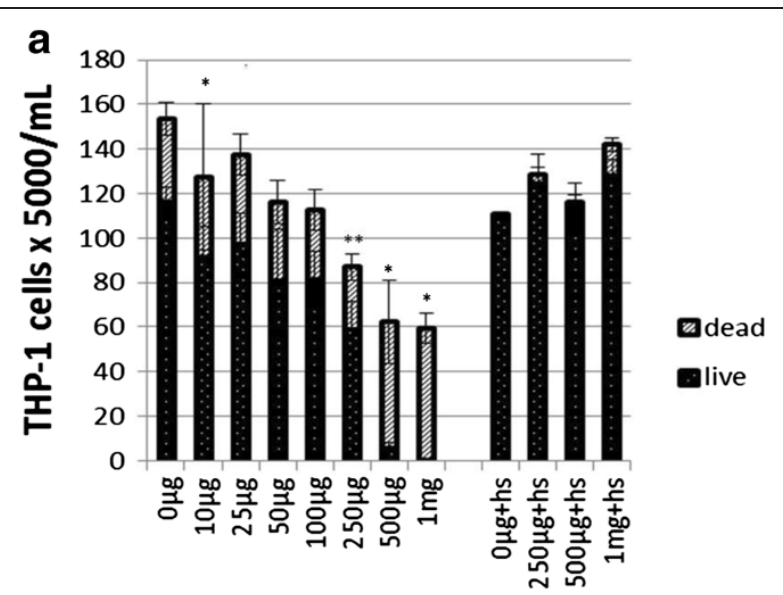

b P.linteus PS concentration

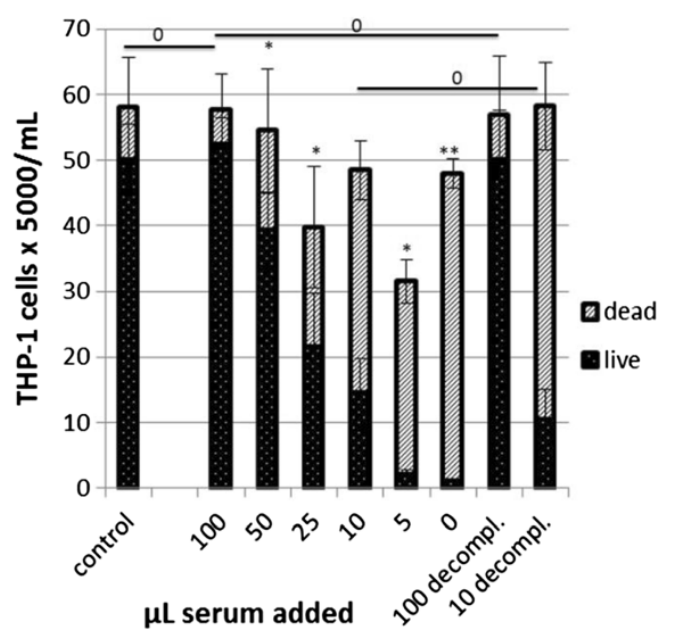

Figure 5 Protective effect of human serum against $P$. linteus polysaccharide extract induced cell death in THP-1 cells (b) compared with the effects of varying $P$. linteus polysaccharide extract concentrations (a). THP-1 cells were cultivated for $24 \mathrm{~h}$ in complete RPMI medium with $100 \mu \mathrm{g} / \mathrm{mL}$ P. linteus polysaccharide extract to which increasing amounts of human serum was added. Cells were stained with trypan blue and non-colored cells were considered "live". Blue cells were considered "dead". A minimum of 1000 cells was counted per point. Figure $5 \mathbf{a}$ shows concentration-dependent cytotoxicity of $P$. linteus polysaccharide extract. In the right section of the figure the effect is shown of simultaneous addition of $100 \mu \mathrm{L}$ of human serum. Figure $5 \mathbf{b}$ shows the concentration-dependent inhibition of $P$. linteus polysaccharide extract cytotoxicity by human serum respectively by decomplemented serum. ${ }^{*} P<0.01,{ }^{*} P<0.05$, significantly different from the values of the previous (lower) concentration in the range; ${ }^{0} p>0.05$ not different between the concentrations indicated.

\section{Polysaccharide- or polyphenol-dependent apoptosis}

As indicated above, both the partially purified polysaccharide extracts and the ethanol extract of $P$. linteus strongly induced apoptosis. When THP-1 cells were incubated for $48 \mathrm{~h}$ in the presence of $2-1000 \mu \mathrm{g} / \mathrm{mL}$ purified $P$. linteus polysaccharide, the MTT assay showed no metabolic effects. Microscopic observation employing acridine orange/ethidium bromide $\mathrm{AO} / \mathrm{EB}$ staining and cell counting revealed that no apoptotic cells were present above the background level (0.1-0.3\%). We had found before that $P$. linteus ethanol extract caused maximum expression of the apoptosis related genes $\mathrm{Bcl}-2$ and Casp-9 in K562 cells [21]. Together this suggested that the polyphenols rather than the polysaccharides cause the apoptotic effects.

Partially purified polysaccharides apparently caused apoptosis due to the content of contaminating polyphenols which had remained in these samples, as already suggested by Kozarski et al. [7]. These antioxidant properties were apparently not protective against apoptosis in THP-1 cells. K562 cells that had been cultivated under the same conditions as THP-1 hardly showed effects of $P$. linteus polysaccharide extract treatment. However, K562 cells carry the glutathione S-transferase P1-1 (GSTP1-1) gene, which conjugates glutathione to electrophilic compounds and exerts strong antioxidative as well as anti-inflammatory effects [40]. The question then becomes whether the apoptosis induction by $P$. linteus is suicide-receptor (TRAIL)- driven (extrinsic) or caused by dysfunctioning mitochondria through ROS -driven insults (intrinsic).

\section{Cell cycle analysis}

Cells were analysed at 24 and $48 \mathrm{~h}$ after start of the treatments. The following treatments were tested: control, PMA, A. bisporus polysaccharide extract, A. brasiliensis polysaccharide extract, human serum, $P$. linteus polysaccharide extract, and $P$. linteus polysaccharide extract combined with human serum. After $24 \mathrm{~h}$, the control cells contained a large percentage of S-phase cells, with a G1/G0 peak of low coefficient of variation (CV) (Figure 7). Treatment with $P$. linteus polysaccharide extracts strongly reduced the synthesizing cells (visible as accumulation of cells in S-phase), while treatment with human serum in combination with the $P$. linteus polysaccharide extract largely repaired the negative effect of the $P$. linteus polysaccharide extract. PMA treatment resulted in a comparable histogram to that obtained after incubation with the $A$. bisporus and $A$. brasiliensis polysaccharide extracts extracts (Figure $7 d$, e and f).

In a separate experiment, cells were analysed for cell cycle progression after 24 and $48 \mathrm{~h}$ of treatment. PCA analysis of these DNA histograms is presented in Figure 8. The main difference in this PCA is the grouping of the individual treatments according to the duration of the treatment, except for $P$. linteus at $48 \mathrm{~h}$. The main eigenvectors for this difference are G0/G1 transition to S/G2 for all treatments (eigenvectors G1, G2, S), except for P. linteus at 24 and $48 \mathrm{~h}$. In the $24 \mathrm{~h} P$. linteus polysaccharide extract-treated sample, a considerable contribution of 

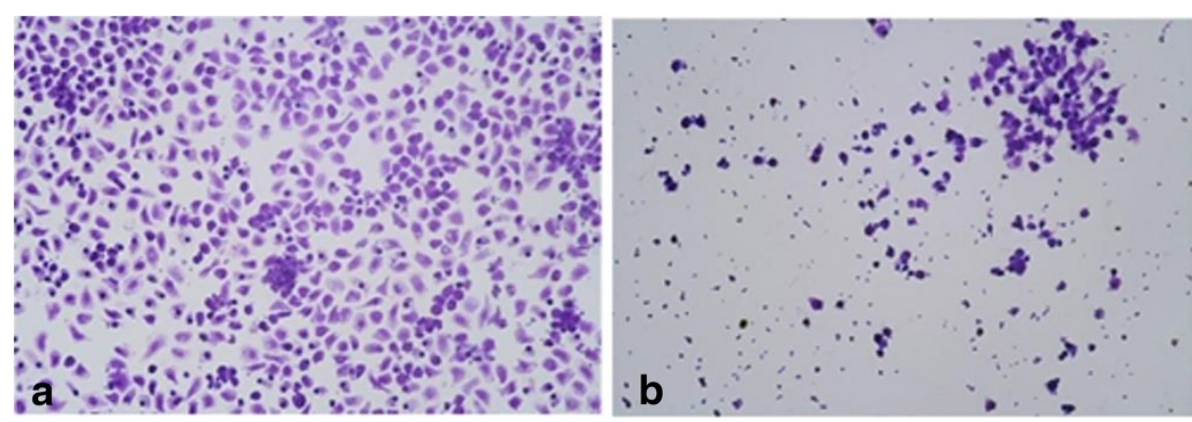

Figure 6 Induction of differentiation in PBMCs by P. linteus polysaccharide extract. (a) Freshly prepared PBMC's (10 cells $/ \mathrm{mL})$ were incubated for $24 \mathrm{~h}$ in medium containing $1 \mathrm{mg} / \mathrm{mL} P$. linteus polysaccharide extract. (b) Control, incubated in medium without $P$. linteus polysaccharide extract. After $24 \mathrm{~h}$ cultivation in a 24 well plate cells were drained,washed with PBS, fixated by $4 \%$ buffered formaldehyde and stained crystal violet.

apoptosis can be seen (eigenvector Below_G1) as nuclei below the G1 level, confirming the microscopic observations. After $48 \mathrm{~h}$, all treatments exhibited a reduction of the number of cells in S and G2 phase through exhaustion of the culture medium.

The treatment combination of the P. linteus polysaccharide extract with human serum recovered the ability of cells to progress through the cell cycle both in the 24 and $48 \mathrm{~h}$-treated samples, confirming the cytological observation with trypan blue exclusion assays. The $48 \mathrm{~h} P$. linteus polysaccharide extract-treated sample showed increases in the mean pulse time (PT_mean, PT_CV), indication of the formation of cell aggregates, and in mean sideward scatter intensity (eigenvector SS_Mean), indicating increased cell density through pyknotic nuclei. Opsonization of the $P$. linteus polysaccharide extract with complete human serum had no effect on its apoptosis-inducing activity, but when the $P$. linteus polysaccharide extract was added to the THP-1 cells before or together with complete or heat-decomplemented human serum, no apoptosis was observed. Instead, the THP-1 cells showed rapid differentiation comparable to
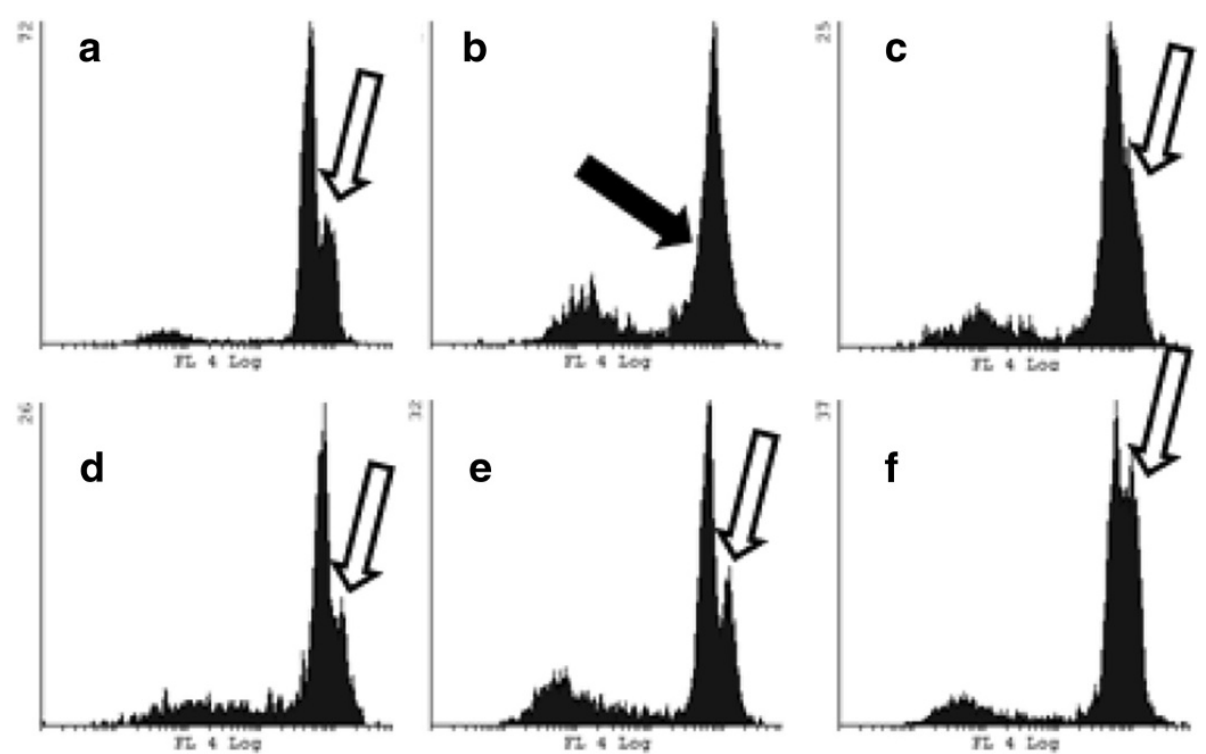

Figure 7 FCM histograms of THP1 cells showing cellular DNA distributions after various treatments. Shown are the histograms at $48 \mathrm{~h}$ of control (a), P. linteus polysaccharide extract (b), P. linteus polysaccharide extract plus HS (c), PMA (d), A. bisporus polysaccharide extract (e) and A. brasiliensis polysaccharide extract (f). Fluorescence intensity of PI is presented on the logarithmic horizontal axis, cell count on the vertical axis. Histogram from cells is gated in FS and SS dotplot to exclude cell aggregates and cellular debris. Treatment with $P$. linteus polysaccharide extract results in cell cycle arrest in G1, with a skewed slope to sub G1 levels due to fragmenting nuclei and dead cells, indicated by the solid arrow in (b). The cell cycle arrest is overcome by cotreatment with $\mathrm{HS}$, resulting in a resumption of DNA synthesis, indicated by the open arrow in (c). In the lower row, extracts from A. bisporus and A. brasiliensis result in comparable DNA profiles as PMA (d) with strong increases of the numbers of cells in the S-phase (open arrows). 


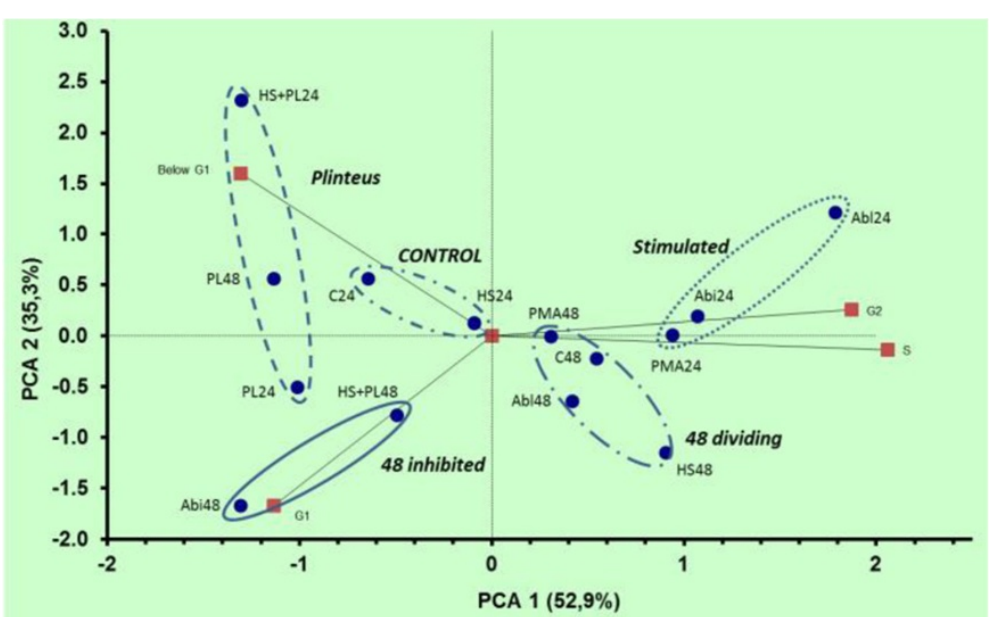

Figure 8 PCA of the DNA flowcytometer data. Data from FCM analysis of propidium iodide (PI) stained cells from each treatment were processed in Cyflogic FCM analysis package according to the following criteria: cells were gated on a window in the pulsetime PI intensity dot plot to exclude cell aggregates. The gated signals were represented as histograms: intensity, pulse time, forward scatter, sideward scatter. In the intensity plot, 4 windows were defined: DNA content below G1 phase of the cell cycle for apoptotic cells (Below G1), the window indicating G0/ G1 phase (G1), a window for S-phase (S) and a window for G2/M phase (G2). In each window, the number of cells was expressed as \% of total cell count in de gating window. The eigenvectors computed from these parameters are indicated on the plot by the small squares. Each dot is a separate treatment, indicated by the treatment code: C: control; PI: P. linteus polysaccharide extract; PI + HS: P. linteus polysaccharide extract complemented with human serum; HS: human serum; PMA: PMA treatment; Abi: A. bisporus polysaccharide extract; Abl: A. brasiliensis polysaccharide extract; codes are followed by the time at which cells were sampled ( $h$ ) after begin of the treatment. A minimum of 1500 cells was counted in the gating window. Similar patterns are grouped and indicated with their most prominent feature in italics: Control for the control and HS24 treatment, Stimulated for the PMA and Agaricus polysaccharide extract treatments at $24 \mathrm{~h}, 48$ dividing for PMA and A. bisporus and A. brasiliensis polysaccharide extracts treatments at $48 \mathrm{~h}, 48$ inhibited for the cells arrested in G1 and $P$. linteus for the $P$. linteus polysaccharide extract treatments, resulting in sub G1 DNA levels due to fragmenting nuclei and dead cells.

the effect of the $A$. bisporus polysaccharide extract and PMA. The inhibitory effect of human serum on $P$. linteus polysaccharide extract induced apoptosis suggested that human serum components might bind to the TRAIL receptor without causing harm. It also suggested that their binding was highly competitive to that of $P$. linteus components, thereby preventing the $P$. linteus polysaccharide extract from inducing apoptosis of THP-1 cells. Laminarin, a standard source of linear $\beta-(1 \rightarrow 3)$ glucan with $\beta-(1 \rightarrow 6)$ side chain, had no effect on THP-1 cell differentiation, and zymosan also showed no effect either. Preincubation of THP-1 cells for 6 hours with $100 \mu \mathrm{g} / \mathrm{mL}$ DMSO-solubilized laminarin before the addition of mushroom polysaccharides extracts or PMA did not change the morphological response of the cells (Table 1).

The $P$. linteus polysaccharide extract seemed to bind to apoptosis-inducing death receptors like the TRAIL receptor on THP-1 cells, which is constitutively expressed in various tissues and upregulated during cell activation. If TRAIL ligands bind to the death receptors on the cell membrane, apoptosis can be induced in (most, but not all) tumor cells, but not in normal cells [41]. Human serum prevents this extrinsic apoptosis induction, presumably through the action of lysophosphatidic acid or sphingosine-1-phosphate resulting in inhibition of caspase8 activation [42]. This renders our hypothesis on the saturation of TRAIL-like receptors by human serum components disputable.

The leukemia derived K562 cells are known to show resistance against TRAIL-induced apoptosis and do not respond to soluble factors that lead to apoptosis in other tumor cells [43]. K562 cells are high in glutathione (GSH) transferase and not very sensitive to ROSinduced apoptosis [44] contrary to THP-1 cells [45]. The strong antioxidant activity of crude $P$. linteus polysaccharides [7] could inhibit the possible intrinsic apoptosis pathway, which usually involves ROS generation and decrease of mitochondrial membrane polarity.

\section{Induction of intracellular ROS and changes in MMP}

To further study the effects of $P$. linteus polysaccharide extract on THP-1 cells, we used the fluorescent dyes dihydroethidine (DHE) and JC-1 to quantify the amounts of ROS induced and the changes in mitochondrial membrane potential, respectively.

$P$. linteus polysaccharide extract gave rise to a concentration dependent increase of intracellular ROS, not much different of the effects of A. bisporus and A. brasiliensis polysaccharide extracts (Figure 9). 
ROS are generated by mitochondrial processes, i.e., by electrons liberated in the respiratory chain complexes I and III that react with electron acceptors and generate free radicals [46]. Oxidative stress occurs when ROS production is not balanced by intracellular antioxidants and antioxidant enzymes, and this may lead to mitochondrial dysfunctioning resulting in necrosis, apoptosis, and autophagy [46].

A. bisporus, $A$. brasiliensis and $P$. linteus polysaccharide extracts both equally increased ROS generation, providing another argument against ROS as the primary cause of the P. linteus-induced apoptosis in THP-1 cells (Figure 9). The A. bisporus polysaccharide extractstreated cells showed a strong effect on aggregation, indicating attached cells by the Mean_PT_DHE and CV_PT_DHE eigenvectors, a hallmark of cell differentiation. The differentiation, i.e., adherence to the wall of the cultivation flask, of THP-1 cells, was correlated with increased polarization of the plasma membrane potential [47] and $\mathrm{Ca}^{2+}$ influx [48]. The $A$. bisporus and $A$. brasiliensis polysaccharide extracts caused depolarization of the MMP while the $P$. linteus polysaccharide extract induced hyperpolarization in a concentrationdependent manner (Figure 9), suggesting that $A$. bisporus and $A$. brasiliensis polysaccharide extracts released mitochondrial $\mathrm{Ca}^{2+}$, thereby increasing cytoplasmic $\mathrm{Ca}^{2+}$ concentration, while $P$. linteus polysaccharide extract increased mitochondrial $\mathrm{Ca}^{2+}$ concentration, resulting in breakdown of the outer mitochondrial membrane and induction of apoptosis [48].

It seems there are two major factors determining differentiation and death of polysaccharide treated THP-1 cells, i.e. a death receptor (TRAIL-like) binding activity on the one hand, and oxidative stress and $\mathrm{Ca}^{2+}$ homeostasis on the other. The discovery that $b c l-2$ modulates intracellular $\mathrm{Ca}^{2+}$ compartmentalization and that caspase cleavage of $\mathrm{Ca}^{2+}$ transporters might cause perturbation of intracellular $\mathrm{Ca}^{2+}$ homeostasis and affects the mode of cell death, provides support for the apoptosis$\mathrm{Ca}^{2+}$ link [48]. The high scavenging activity of $P$. linteus polysaccharide extract, and even more so that of the ethanol extract, make the intrinsic apoptosis pathway rather unlikely as the primary cause of apoptosis in THP-1 cells. Taken together with the finding of concentration dependent increase of the MMP of THP-1 cells upon treatment with $P$. linteus polysaccharide extract and the inhibition of this effect by human serum, it is likely that the apoptosis of THP-1 cells induced by the P. linteus extract can only be caused by TRAIL receptor binding, thus triggering the mitochondrial pathway indirectly. Apoptosis through the mitochondrial pathway merely seems to be caused by disturbance of the mitochondrial $\mathrm{Ca}^{2+}$ homeostasis [49].

Changes in the MMP and $\mathrm{Ca}^{2+}$ homeostasis play a prominent role in the pathogenesis of age related loss of neuronal function, such as that occurring in Alzheimer's

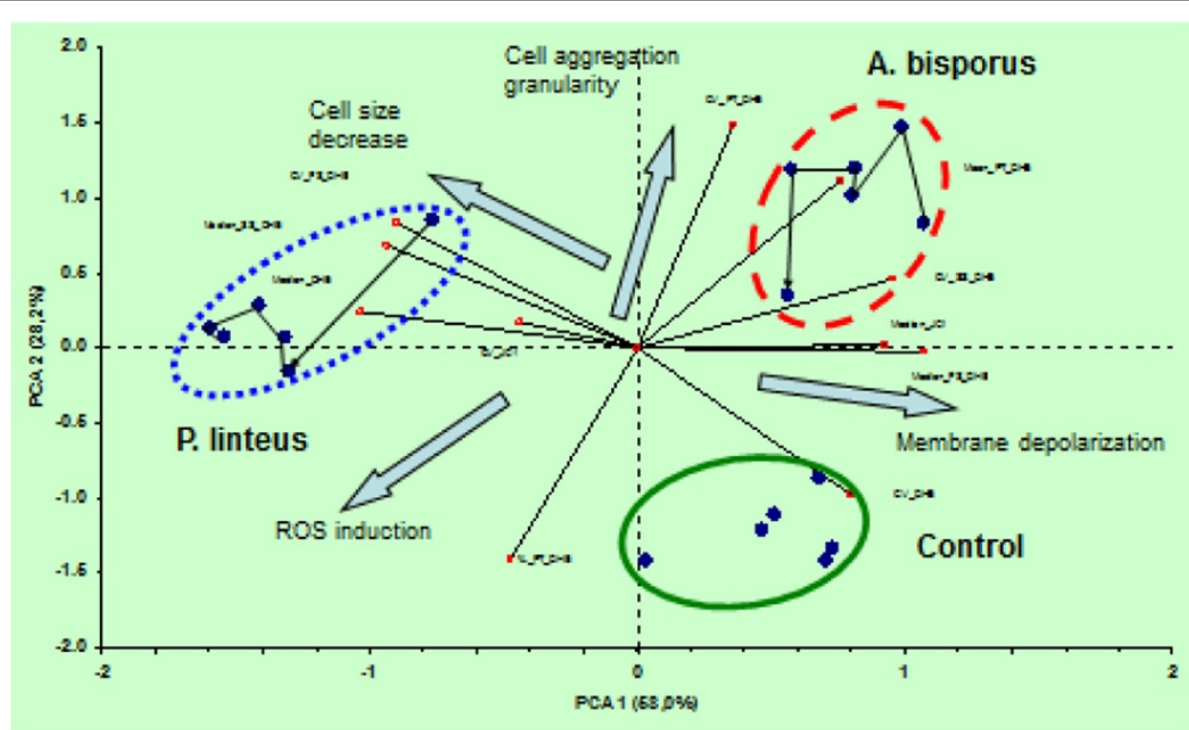

Figure 9 PCA of DHE and JC-1 stained THP-1 cells. Data from DHE and JC-1 stained cells were gated on forward and sideward scatter and processed by StatistiXl plug in for Excel. Selected parameters are: JC1 fluorescence intensity histogram: Median (Median_JC1), CV (CV_JC1); DHE fluorescence intensity histogram: median (Median_DHE), CV (CV_DHE); forward scatter on DHE signal histogram: median (FS_median_DHE), CV (CV_FS_DHE), sideward scatter: Median (Median_SS_DHE), CV (CV_SS_DHE); pulse time on DHE signal: mean (Mean_PT_DHE), CV (CV_PT_DHE) and\% of total (\%_PT_DHE). All eigenvectors computed from these parameters are indicated on the plot by the small squares, marked with the related vector code. The big arrows indicate the vectors for the observed cellular properties, extracted from the PCA. The marked populations comprise the different treatments, with each dot an individual treatment. Treatments are mentioned in the text, and are connected by the solid lines, the arrowheads indicate the increasing concentration of the extracts applied. A minimum of 3000 cells in the FS, SS gate was counted. 
disease [50] and Parkinson's disease [51]. Hyperpolarizing compounds in $P$. linteus might restore $\mathrm{Ca}^{2+}$ homeostasis and thereby prevent the loss of neuronal function.

\section{Conclusion}

$P$. linteus polysaccharide extracts caused apoptosis of THP-1 monocytes whereas these cells differentiated into macrophages in the presence of $A$. bisporus and of $A$. brasiliensis polysaccharide extracts. Human serum protected THP-1 cells against apoptosis by P. linteus polysaccharide extract. All polysaccharide extracts increased ROS in THP-1cells. P. linteus polysaccharide extract increased MMP, whereas A. bisporus and A. brasiliensis polysaccharide extracts decreased MMP. P. linteus derived compounds that strongly influence MMP and ROS may provide useful tools for the study of age related neurodegenerative diseases.

\begin{abstract}
Abbreviations
ANOVA: Analysis of variance; AO: Acridine orange; ATCC: American type culture collection; COX-2: Cyclooxygenase-2; CV: Coefficient of variance; DHE: Dihydroethidine; DPPH: 1, 1-diphenyl-2-picrylhydrazyl radical; EB: Ethidium bromide; FCM: Flow cytometry; HS: Human serum; $I_{50}$ : 50\% inhibitory concentration; IL-10: Interleukin-10; JC-1: Membrane permeant dye to measure mitochondrial membrane potential; LSD: Least significant difference; MAPK: Mitogen activated protein kinase; MMP: Mitochondrial membrane potential; MMP-9: Matrix metallopeptidase-9; MTT: Tetrazolium compound for measuring mitochondrial metabolic activity; NF-KB: Nuclea factor KB; OMM: Outer mitochondrial membrane; PBMC: Peripheral blood monocytic cell; PBS: Phosphate-buffered saline; PCA: Principal component analysis; PI: Propidium iodide; PMA: Phorbol myristate acetate; PS: Polysaccharide; ROS: Reactive oxygen species; TCA: Trichloacetic acid; TRAIL: Tumor necrosis factor related apoptosis inducing ligand.
\end{abstract}

\section{Competing interests}

Amazing Grace Health Industries of Bangkok, Thailand, contributed to the costs of laboratory rental and materials of LLDVG.

\section{Authors' contributions}

LLDVG and HV conceived and designed the study. LJLDVG and HV performed experiments. HV interpreted the results. LJLDVG wrote the manuscript. Both authors read and approved the manuscript.

Received: 6 March 2013 Accepted: 8 December 2013

Published: 18 December 2013

\section{References}

1. Shibata Y, Kurita DS, Okugi H, Yamanaka H: Dramatic remission of hormone refractory prostate cancer Achieved with extract of the mushroom, Phellinus linteus. Urol Intern 2004, 73:188-190.

2. Nam SW, Han JY, Kim Jl, Park SH, Cho SH, Han NI, Yang MY, Kim JK, Choi SW, Lee YS, Chung KW, Sun HS: Spontaneous regression of a large hepatocellular carcinoma with skull metastasis. J Gastroenterol Hepatol 2005, 20:488-492.

3. Rop O, Mlcek J, Jurikova T: Beta-glucans in higher fungi and their health effects. Nutr Rev 2009, 67:624-631.

4. Moradali MF, Mostafavi H, Ghods S, Hedjaroude GA: Immunomodulating and anticancer agents in the realm of macromycetes fungi (macrofungi). Int Immunopharmacol 2007, 7:701-724.

5. Kim HG, Yoon DH, Lee WH, Han SK, Shresta B, Kim CH, Lim MH, Chang W, Lim S, Choi S, Song WO, Sung JM, Hwang KC, Kim TW: Phellinus linteus inhibits inflammatory mediators by suppressing redox-based NF-kB and MAPKs activation in lipopolysaccharide-induced RAW 264.7 macrophage. J Ethnopharm 2005, 114:307-315.
6. Huang GJ, Hsieh WT, Chang HY, Huang SS, Lin YC, Kuo YH: a-Glucosidase and aldolase inhibitory activities from the fruiting body of Phellinus merrillii. J Agr Food Chem 2011, 59:5702-5706.

7. Kozarski M, Klaus A, Niksic M, Jakovljevic D, Todorovic N, Van Griensven LJLD: Antioxidative and immunostimulating activities of polysaccharide extracts of the medicinal mushrooms Agaricus bisporus, Agaricus brasiliensis, Ganoderma lucidum and Phellinus linteus. Food Chem 2011, 129:1667-1675.

8. Ashkenazi A, Holland P, Eckhardt SG: Ligand-based targeting of apoptosis in cancer: the potential of recombinant human apoptosis ligand2/tumor necrosis factor-related apoptosis-inducing ligand (rhApo2L/TRAIL). J Clin Oncol 2008, 26:3621-3630.

9. Fulda S, Debatin K-M: Extrinsic versus intrinsic apoptosis pathways in anticancer chemotherapy. Oncogene 2006, 25:4798-4811.

10. Hanahan D, Weinberg RA: Hallmarks of cancer: the next generation. Cell 2011, 144:646-674.

11. Elmore S: Apoptosis: a review of programmed cell death. Toxicol Pathol 2007, 35:495-516.

12. Han $S B$, Lee $C W$, Jeon $Y$ J, et al: The inhibitory effect of polysaccharides isolated from Phellinus linteus on tumor growth and metastasis. Immunopharmacol 1999, 41:157-164.

13. Collins L, Zhu T, Guo J, et al: Phellinus linteus sensitizes apoptosis induced by doxorubicin in prostate cancer. Br J Cancer 2006, 95:282-288.

14. Tsuji T, Du W, Chen L, Yamamoto D, Chen CY: Phellinus linteus extract sensitizes advanced prostate cancer cells to apoptosis in athymic nude mice. PLOS One 2010, 5:3e9885.

15. Lee IK, Yun BS: Styrylpyrone-class compounds from medicinal fungi Phellinus and Inonotus spp. and their medicinal importance. J Antibiot 2011, 64:349-359.

16. Sliva D, Jedinak A, Kawasaki J, Harvey K, Slivova V: Phellinus linteus suppresses growth, angiogenesis and invasive behaviour of breast cancer cells through the inhibition of AKT signaling. Br J Cancer 2008, 98:1348-1356.

17. Zhu T, Kim SH, Chen CY: A medicinal mushroom: Phellinus linteus. Curr Med Chem 2008, 15:1330-1335.

18. Guo J, Zhu T, Collins L, Xiao ZX, Kim SH, et al: Modulation of lung cancer growth arrest and apoptosis by Phellinus linteus. Mol Carcinog 2007, 46:144-154.

19. Song KS, Li G, Jing K, Kim TD, Seo SB, Yoo JK, Park HD, Hwang BD, Lim K, Yoon WH: Protein bound polysaccharide from Phellinus linteus inhibits tumor growth, invasion, and angiogenesis and alters Wnt/b-catenin in SW480 human colon cancer cells. BMC Cancer 2011, 11:307.

20. Huang GJ, Huang SS, Deng JS: Anti-inflammatory activities of inotilone from Phellinus linteus through the inhibition of MMP-9, NF-kB and MAPK activation in vitro and in vivo. PLOS One 2012, 7(5):e35992.

21. Shnyreva AV, Song W, Van Griensven LLD: Extracts of medicinal mushrooms Agaricus bisporus and Phellinus linteus induce proapoptotic effects in the human leukemia cell line K562. Int J Med Mushr 2010, 12:67-175.

22. Park IH, Jeon SY, Lee HJ, Kim SI, Song KS: A $\beta$-secretase (BACE-1) inhibitor hispidin from the mycelial cultures of Phellinus linteus. Planta Med 2004, 70:143-146.

23. Suzuki S, Kawamata T, Okada Y, Kobayashi T, Nakamura T, Hori T: Filtrate of Phellinus linteus broth culture reduces infarct size significantly in a rat model of permanent focal cerebral ischemia. Evid Based Compl Altern Med 2011, ID:326319. doi:10.1093/ecam/nen091.

24. Wang $H$, Wu G, Park H, Jiang PP, Sit W-H, van Griensven LJLD, Wan JM-F: Protective effect of Phellinus linteus polysaccharide extracts against thioacetamide-induced liver fibrosis in rats: a proteomics analysis. Chin Med 2012, 7:23.

25. Tsuchiya S, Yamabe M, Yamaguchi Y, et al: Establishment and characterization of a human acute monocytic leukemia cell line (THP-1). Int J Cancer 1980, 26:171-176.

26. Brown GD, Gordon S: Immune recognition. A new receptor for beta-glucans. Nature 2001, 412:36-37.

27. Mosser DM, Edwards JP: Exploring the full spectrum of macrophage activation. Nat Rev Immunol 2008, 8:958-969.

28. Kim MO, Moon DO, Jung JM, Lee WS, Choi YH, Kim GY: Agaricus blazei extract induces apoptosis through ROS-dependent JNK activation involving the mitochondrial pathway and suppression of constitutive NF-\{kappa\}B in THP-1 cells. Evid Based Altern Complem Med 2011, ID:838172. doi:10 1093/ecam/nep176. 
29. Sevag MG: Eine neue physikalische Enteiweißungsmethode zur Darstellung biologisch wirksamer Substanzen. Biochem Z 1934, 273:419-429.

30. DuBois M, Gilles KA, Hamilton JK, Reders PA, Smith F: Colorimetric method for determination of sugars and related substances. Anal Chem 1956, 28:350-356

31. Ainsworth EA, Gillespie KM: Estimation of total phenolic content and other oxidation substrates in plant tissues using Folin-Ciocalteu reagent. Nat Protoc 2007, 2:875-877.

32. Bradford MM: A refined and sensitive method for the quantitation of microgram quantities of protein using the principle of protein-dye binding. Anal Biochem 1976, 72:248-255.

33. Smiderle FR, Ruthes A, van Arkel J, Chanput W, lacomini M, Wichers HJ, van Griensven LJLD: Polysaccharides from Agaricus bisporus and Agaricus brasiliensis show similarities in their structures and their immunomodulatory effects on human monocytic THP-1 cells. Compl Altern Med 2011, 11:58.

34. Daigneault M, Preston JA, Marriott HM, Whyte MKB, Dockrell DH: The identification of markers of macrophage differentiation in PMA-stimulated THP-1 cells and monocyte-derived macrophages. PLOS One 2010, 5(1):e8668.

35. Williams $\mathrm{DL}$, McNamee $\mathrm{RB}$, Jones $\mathrm{EL}$, et al: $\mathrm{A}$ method for the solubilization of a (1-3)- $\beta$-D-glucan isolated from Saccharomyces cerevisiae. Carbohydr Res 1999, 219:203-213.

36. Shao S, Hernandez M, Kramer JKG, Rinker DL, Tsao R: Ergosterol profiles, fatty acid composition, and antioxidant activities of button mushrooms as affected by tissue and devbelopmental stage. J Agric Food Chem 2010, 58:11616-11625.

37. Phillips KM, Horst RL, Koszewski NJ, Simon RR: Vitamin $D_{4}$ in mushrooms. PLOS One 2012, 7(8):e40702.

38. Chen TC, Persons KS, Lu Z, Mathieu JS, Holick MF: An evaluation of the biologic activity and vitaminD receptor binding affinity of the photoisomers of vitamin D3 and previtamin D3. J Nutr Biochem 2000, 11:267-272

39. Shimizu T, Maeno E, Okada Y: Prerequisite role of persistent cell shrinkage in apoptosis of human epithelial cells. Acta Physio/ Sin 2007, 59:512-516.

40. Wiley SR, Schooley K, Smolak PJ, et al: Identification and characterization of a new member of the TNF family that induces apoptosis. Immunity 1995, 3:673-682

41. Morceau F, Duvoix A, Delhalle S, Schnekenburger M, Dicato M, Diederich M: Regulation of glutathione S-transferase P1-1 gene expression by NF-kappaB in tumor necrosis factor alpha-treated K562 leukemia cells. Biochem Pharmacol 2004, 67(7):1227-1238.

42. Kang YC, Kim KM, Lee KS, et al: Serum bioactive lysophospholipids prevent TRAIL induced apoptosis via P13K/Akt-dependent CFLIP expression and Bad phosphorylation. Cell Death Diff 2004 11:1287-1298.

43. Kim MJ, Kim HB, Bae JH, et al: Sensitization of human K562 leukemic cells to TRAIL-induced apoptosis by inhibiting the DNA-PKcs/Akt-mediated cell survival pathway. Biochem Pharmacol 2009, 78:573-582.

44. Fernandes RS, Cotter TG: Apoptosis or necrosis: intracellular levels of glutathione influence mode of cell death. Biochem Pharmacol 1994, 48:675-681.

45. Seo GS, Lee SH, Choi SC, et al: Iron chelator induces THP-1 cell differentiation potentially by modulating intracellular glutathione levels. Free Rad Biol Med 2006, 40:1502-1512.

46. Park J, Lee J, Choi C: Mitochondrial network determines intracellular ROS dynamics and sensitivity to oxidative stress through switching inter-mitochondrial messengers. PLOS One 2011, 6(8):e 2321.

47. Colden-Stanfield M, Scanlon M: VCAM-1-induced inwardly rectifying $\mathrm{K}^{+}$ current enhances $\mathrm{Ca}^{2+}$ entry in human THP-1 monocytes. Am J Physiol 2000, 279:C488-C494.

48. Orrenius S, Zhivotovsky B, Nicotera P: Regulation of cell death: the calcium-apoptosis link. Nat Rev Mol Cell Biol 2003, 4:552-565.

49. Giorgi G, Baldassari F, Bononi A, Bonora $\mathrm{M}$, et al: Mitochondrial $\mathrm{Ca}^{2+}$ and apoptosis. Cell Calcium 2012, 52(2):36-43.
50. Blanchard BJ, Stockwell BR, Ingram VM: Eliminating membrane depolarization caused by the Alzheimer peptide $A \beta(1-42$, aggr.). Biochem Biophys Res Comm 2002, 293:1204-1208.

51. Ho PWL, Ho JWM, Liu HF, So DHF, Tse ZHM, Chan KH, Ramsden DB, Ho SL: Mitochondrial neuronal uncoupling proteins: a target for potential disease-modification in Parkinson's disease. Translat Neurodegen 2012, 1:3.

doi:10.1186/1749-8546-8-25

Cite this article as: van Griensven and Verhoeven: Phellinus linteus polysaccharide extracts increase the mitochondrial membrane potential and cause apoptotic death of THP-1 monocytes. Chinese Medicine 2013 8:25.

\section{Submit your next manuscript to BioMed Central and take full advantage of:}

- Convenient online submission

- Thorough peer review

- No space constraints or color figure charges

- Immediate publication on acceptance

- Inclusion in PubMed, CAS, Scopus and Google Scholar

- Research which is freely available for redistribution

Submit your manuscript at www.biomedcentral.com/submit
C Biomed Central 